\title{
Is It Because I Can or Because of Who I Am? \\ The Moderating Effect of Entrepreneurs' Social Identity on Entrepreneurial Self-Efficacys' - Entrepreneurial Intention Relationship
}

\author{
María Laura Gonzalez-Canosa ${ }^{1}$, Fabian Osorio-Tinoco ${ }^{*}$, Joan-Lluís Capelleras Segura ${ }^{2}$, \\ Catherine Krauss-Delorme ${ }^{3}$, Fernando Pereira-Laverde ${ }^{2}$
}

\begin{abstract}
The main purpose of this paper is to examine whether potential entrepreneurs are mainly driven by entrepreneurial skills or by a social identity to engage in entrepreneurial behaviors. Using a sample of 696 Colombian students from the data of Global University Entrepreneurial Spirit Students'Survey (GUESSS), findings confirm Darwinian and Missionary social identity influence entrepreneurial intention positively. Furthermore, we find that the more a person identifies with a Darwinian social identity, the less entrepreneurial intention depends on entrepreneurial self-efficacy, while the contrary happens for missionary social identity. This study provides empirical evidence that competence, and identification influence the entrepreneurial process. Additionally, this study provides an explanation in a new setting, about why some individuals with strong entrepreneurial self-efficacy do not exhibit strong entrepreneurial intention.
\end{abstract}

Keywords Social identity; Entrepreneurial self-efficacy; Entrepreneurial intention; Darwinian; Communitarian; Missionary.

Submitted: August $9^{\text {th }}, 2021 /$ Approved: December $1^{\text {st }}, 2021$

\section{Introduction}

In order to better understand entrepreneurship, scholars historically have examined the central question: Why, when, and how some individuals are becoming entrepreneurs. In this sense, entrepreneurhip research acknowledges the intentionality of entrepreneurial behavior being entrepreneurial intention the most proximal predictor of the decision to engage in entrepreneurial activities (Obschonka et al., 2012). Thus, there is a great deal of research into this question taking into consideration extant conditions that either support or impede entrepreneurial intentions.

Self-perception has emerged as a fruitful field of research on entrepreneurship as its incidence on entrepreneur's decisions has been demonstrated. The relationship between entrepreneurial behavior and perceptions has been focused mainly from the viewpoint that perception influences entrepreneurial behavior (Hogg et al., 1998). These studies focus upon and refer mostly to two concepts, self-efficacy and identity (Estrada Cruz et al., 2019).

In entrepreneurship, the most widely studied construct about perceived ability levels is entrepreneurial self-efficacy, which refers to an individual's perception of his/her own capability to perform a task aimed at entrepreneurial actions. The research in entrepreneurial selfefficacy has found a significant and positive link with entrepreneurial intentions of different kinds of individuals and in both developed and developing countries (Newman et al., 2019). Hence, entrepreneurial self-efficacy has been emphasized as a part of general skill set needed to succeed in entrepreneurial behavior.
The other self-perception concept to explain how individuals think and act entrepreneurally is perceived identity. To assume an entrepreneurial identity means that an individual mentally frames certain situations as being entrepreneurial and according to this adjusts his/her behavior accordingly. In this study, we investigated different types of entrepreneurial social identities. The social identity theory post that individuals tend to identify with groups and if they do so, a particular social identity influences personal decision-making processes (Obschonka et al., 2012). Scholars have shown increased interest in identity in entrepreneurship (Radu-Lefevre et al., 2021). This research has yielded a wealth of insights into how self definitions of entrepreneurs develop and influence decisions and behaviors (Fauchart \& Gruber, 2011). Perception of the possible self as an entrepreneur can be an important motivational mechanism in the nascent entrepreneurial process and a strong precursor of entrepreneurial intention.

However, even though both entrepreneurial self-efficacy and entrepreneurial identity are key concepts for the formation of entrepreneurial intention, their study has been done in a separate way. Furthermore, considering that entrepreneurs represent heterogeneous individuals who do not possess a unitary personality type or a specific set of psychological traits, surprisingly there is little research that relates entrepreneurial self-efficacy and entrepreneurial identity in its formation. For instance, Ceresia and Mendola (2020) recently posit that more research is needed to uncover the relation between these variables. In this vein, recent research shows self-efficacy and perception of self may play a prominent role in shaping entrepreneurial intention (e.g. Donaldson, 2019; Hand et al., 2020; Ko \& Kim, 2020). It is thus important to determine whether

(1) Pontificia Universidad Javeriana Cali, Colombia.

(2) Universitat Autònoma de Barcelona, España.

(3) Universidad Católica de Uruguay, Uruguay

*Corresponding author: fosorio@javerianacali.edu.co 
potential entrepreneurs are mainly driven by entrepreneurial skills or by a social identity to engage in entrepreneurial behaviors. Besides, considering that the entrepreneur makes decisions based on the heuristic forms or set of means that include identity (Who am I) and personal skills (What I know), it is necessary to know how they interact so understand how, when, and why entrepreneurial behavior will occur.

Specifically, this study aims to contribute to the existing literature in two ways: First, the relationship between entrepreneur's social identity and entrepreneurial intention has not been satisfactorily studied and heterogeneity in social identities has often been despised (Fauchart \& Gruber, 2011; Obschonka et al., 2015). Second, only a handful of entrepreneurship studies have considered both components of self-perception simultaneously, perceived ability and perceived identity (Ko \& Kim, 2020).

This research proceeds as follows. First, we present the theoretical background. Next, we develop our hypotheses and after we describe the origin of the data, the variables, and the empirical model. Then, we present our findings and discuss the implications and limitations of this study.

\section{Theoretical Background and Hypotheses development}

Within self-perception studies, the concept of self-efficacy developed by Bandura (1982), is one of the most important notions to emerge in the perceived ability area. Self-efficacy is an important determinant of human behavior as individuals tend to evade tasks about which they have low self-efficacy and, are drawn toward tasks about which they have high self-efficacy. Entrepreneurship literature adopted this concept by the development of the construct of entrepreneurial selfefficacy. This construct allows capturing the degree to which individuals believe that they are capable of performing the tasks associated with new-venture. ESE has been considered one of the main drivers of entrepreneurial intentions. (Newman et al., 2019).

In this vein of self-perception, a growing number of studies have turned to identity theory to explain entrepreneurial intention formation (e.g., Murnieks et al., 2020; Wry \& York, 2017). Self-identity as an entrepreneur has been considered as a predictor of entrepreneurial intention with authors finding mostly a direct positive effect. Smith \& Woodworth (2012) focus on Missionary social identity and state that social entrepreneurship education influences the development of a missionary social identity which increases entrepreneurial intention. Furthermore, Shepherd et al. (2015) performed a literature review on entrepreneurial intention and concluded that social identity motivates the decision to create a new venture.

Identity is by nature multidimensional. Considering entrepreneurial identity as a unique dimension would leave out the inherent differences present in identity as entrepreneurs have different motivations, self-evaluate in terms of different things, and compare to different types of persons. An individual's social identity as a founder varies in terms of their basic social motivation (why do they create the entrepreneurial venture), their basis of self-evaluation (how do they evaluate themselves) and their frame of reference (whom do they compare to). In this sense, Fauchart \& Gruber (2011) posit three different social identity types, Darwinians, Communitarians, and Missionaries. These authors called Darwinians those entrepreneurs whose main social motivation is to make money, while their basis of self-evaluation is their ability to apply solid business competencies and their frame of reference is their competitors. Communitarians, on the other hand, were defined as founders that consider their ability to give to their community as their basic social motivation; they evaluate themselves in terms of their authenticity and, their frame of reference is the members of their community. Finally, missionary founders were classified as entrepreneurs for whom advancing a particular cause is their basic social motivation; they consider themselves socially responsible and self-evaluate in these terms. Their frame of reference is the society.

Social identities as Darwinian, Communitarian and Missionary have dissimilar effects on several entrepreneurship-related variables as shown by previous research. Brändle et al. (2018) found a direct positive effect of Darwinian and Communitarian social identity on entrepreneurial self-efficacy. Lheureux \& Auzoult (2017) described a direct positive influence of self-typicality and ties dimensions of social identity on entrepreneurial self-efficacy, while Murnieks et al. (2020) found a direct positive effect of entrepreneurial identity centrality on entrepreneurial self-efficacy. All this prior literature provides useful insights and serves as a basis to understand how entrepreneurial selfefficacy and social entrepreneurial identity affect the entrepreneurial intention. However, this research ignores the potential associated with the conjoint analysis of each self perception concepts in the formation of entreprenurial intention. Furthermore, their findings remain separate and controversial.

\subsection{Entrepreneurial self-efficacy and intention.}

Entrepreneurial self-efficacy is a useful concept for explaining human behavior as research reveals that it plays an influential role in determining an individual's choice for entrepreneurship. Individuals who are very confident in their entrepreneurial skills and capabilities will be more likely to form entrepreneurial intentions. This is supported by entrepreneurship research and recent systematic reviews (Newman et al., 2019). According to this the following hypothesis is stated:

Hypothesis 1: Entrepreneurial self-efficacy influences positively entrepreneurial intention.

\subsection{Entrepreneurial social identities and intention.}

Firm creation processes and outcomes are shaped by personal expression which is a common characteristic in every entrepreneurial venture (Sieger et al., 2016). Following identity theory people avoid a misfit between social identity and behavior. According to Obschonka et al. (2012), social identity influences the cognitive processes that underlie the intention formation and how we see ourselves has a great deal to do with how we act. Following Lheureux \& Auzoult (2017), the more the entrepreneurial social identity evokes positive affects and strong feelings of ties, the more the individual thinks that 
creating their business would be desirable. Accordingly, social identification as an entrepreneur should increase entrepreneurial intentions.

Social identity varies among different levels of inclusiveness in people's social motivations. Furthermore, an individual's social identity fluctuates in terms of their basic social motivation, their basis of self-evaluation and their frame of reference. Social identities as described by Fauchart \& Gruber (2011) have previously shown diverse effects over entrepreneurial intention-related variables. (e.g. Brändle et al., 2018; Estrada Cruz et al., 2019; Lheureux \& Auzoult, 2017; Murnieks et al., 2020; Wry \& York, 2017). Identities are a source of motivation for actions that result in social validation of self-meaning so we expect entrepreneurial intention to be a way for individuals to validate their identity as darwinians, communitarians or missionaries.

Darwinian entrepreneurs are associated with the classical view of entrepreneurship where entrepreneurial activity is conceptualized as intentional, planned and purely economically driven (Fauchart \& Gruber, 2011). These individuals identify with the group of entrepreneurs strongly and are interested in creating wealth for themselves, consequently, we expect Darwinians to build a firm to enact their identity as "born to be" entrepreneurs (Malmstrom \& Oqvist, 2021). Developing an entrepreneurial activity that fits one's self-concept generates positive emotions which reinforces the intention of Darwinians (who are very self-centered) to engage in the entrepreneurial process (Brändle et al., 2018).

Hypothesis 2a: Darwinian social identity influences positively entrepreneurial intention.

Entrepreneurs with a communitarian social identity are less motivated by the financial aspects of entrepreneurship and more by providing value to their community. Communitarians who are unsatisfied with existing market offerings are likely to adapt products and/ or services to satisfy their needs and the needs of people like them. Communitarians start selling to friends and see their firms as opportunities to impact positively their community. They see their entrepreneurial activities as important for the development of the community (Fauchart \& Gruber, 2011). They intend to give to a group they toughly identify with and define success as delivering value to their community (Ko \& Kim, 2020). Communitarians enact their identity by creating an entrepreneurial venture as they realize the products, they had designed for themselves are of interest to fellow community members (Daskalopoulou \& Skandalis, 2019). Consequently, we hypothesize the following:

Hypothesis 2b: Communitarian social identity influences positively entrepreneurial intention.

Missionaries are individuals that prioritize social aims. Searching for a way to impact society and enact their identity as both entrepreneurs and change-makers they develop an entrepreneurial intention and use their ventures as vehicles for change (Fauchart \& Gruber, 2011). To enact their identity as change-makers, missionaries create a venture to address social problems (Wry \& York, 2017). Join in entrepreneurial activities according to with roles that are meaningful to individuals to the missionary identity result in positive feelings that affect missionaries' decision to become entrepreneurs. Furthermore, developing a social entrepreneurial project which motivates missionary identity has been proved fruitful to influence students' intention to become entrepreneurs (Ko \& Kim, 2020; Smith \& Woodworth, 2012). Therefore, the following hypothesis is stated:

Hypothesis 2c: Missionary social identity influences positively entrepreneurial intention.

\subsection{Entrepreneurial social identities, self-efficacy and intention.} Identity activation and expression are particularly important in the vocational area because vocational behavior is a major channel through which people can enact their self-concept (Super, 1963). People feel internally accountable to live out their identities because doing so produces feelings of legitimacy and self-worth. Consequently, developing an entrepreneurial activity that fits one's self-concept allows for enduring self-verification generating positive emotions (Wry \& York, 2017). When deciding to engage in entrepreneurship, individuals will consider jointly whether they have the abilities demanded by the task (entrepreneurial self-efficacy) and whether performing the task matches their identity. However, personal factors as self-efficacy may be affected when one's identity as a group member is more or less salient than one's identity as a unique person (Terry \& Hogg, 1996). While Individuals are drawn toward tasks about which they have high selfefficacy and thus are more likely to choose occupations where they feel efficacious, people have a strong motivation to avoid a misfit between social identity and behavior (Super, 1963). Thus, if one perceives a low level of fit with entrepreneurship or no fit, the entrepreneurial intention will be low, regardless of entrepreneurial self-efficacy.

Darwinian entrepreneurs consider themselves as natural firm founders (Gruber \& MacMillan, 2017), and have usually greater entrepreneurial education than other entrepreneurs (Brändle et al, 2018). Besides, Darwinians consider their identity deeply entangled with entrepreneurial behaviors (Sieger et al., 2016). Theory of identity predicts that self-identity tied to a behavior becomes a more salient aspect of an individual's overall self-concept (Charng, 1988). Therefore, their identity to increase their entrepreneurial intentions is more suitable by the perception of whom they consider themselves to be (natural firm founders) and less by the perception of their abilities. In this regard, the effect of entrepreneurial self-efficacy on entrepreneurial intention should loom weaker when individuals have a salient Darwinian social identity. Even when entrepreneurial self-efficacy is low, Darwinians still engage in entrepreneurial behavior.

Hypothesis 3a: When identification with Darwinian social identity is high, the positive relationship between entrepreneurial self-efficacy and entrepreneurial intention is weaker.

Communitarians consider themselves as entrepreneurs as long as they receive positive feedback and support form their fellow community members (Gruber \& MacMillan, 2017) Daskalopoulou \& Skandalis 
(2019) state that the relationship between consumer membership in a field and, the skills, competences, and community an entrepreneur has influence how communitarian entrepreneurs convert forms of non-material and material capital to create businesses. Communitarians identify with the worldview of their community and engage in consumption activities in the process of gaining entrepreneurial legitimation within a specific field. Furthermore, they value the support they receive from fellow community members (Gruber \& MacMillan, 2017).

Communitarians' relationship with entrepreneurship is almost accidental at first as they usually create their entrepreneurial product for themselves. After receiving positive feedback from the community towards which they identify and recognizing the value their community members assign to their product, the communitarian founder takes the next step and engages in entrepreneurship. When group identification is salient, self-categorization theory predicts that individuals separate from their individuality and become less selfconscious (Hogg \& Hains, 1998) thus, it should be their identity as group members and not so much the perception of their abilities that motivates Communitarians to engage in entrepreneurship.

Self-efficacy is a personal factor that may be expected to have a weaker influence when one's identity as a group member is more salient than one's identity as a unique person (Terry \& Hogg, 1996). Thus, when an individual's Communitarian identity is salient, we expect the effect of entrepreneurial self-efficacy on entrepreneurial intention to loom weaker. This would mean that even when Communitarians find they might not have enough capacities to fulfill entrepreneurial tasks, they may still engage in entrepreneurship if they receive constant feedback from their fellow community members indicating they value their entrepreneurial product. As their behavior fits whom they consider themselves to be (engaged members of a community) communitarians may rely more on the intention generated through the identification with their community and less on the effect their entrepreneurial self-efficacy may have.

Hypothesis 3b: When identification with Communitarian social identity is high, the positive relationship between entrepreneurial self-efficacy and entrepreneurial intention is weaker.

Finally, people who identify with a missionary social identity do not consider themselves as natural firm founders (as Darwinians) neither have had previous experience with a product for which they have received positive feedback and motivated them to become entrepreneurs (as Communitarians) but rather find entrepreneurship as a way to fulfill what they perceive as their mission, to contribute to the world (Brändle et al., 2018). Missionaries will undertake entrepreneurship only if they anticipate success in fulfilling their main task, impact society positively (Brändle et al., 2018).

Missionaries' main goal is to help society as a whole and consider financial revenue as a way to support their main objective. As they aim for a bigger objective than developing the firm on itself, their selfimposed responsibility may lead to anxiety if they anticipate failing to meet that aspiration by having a low entrepreneurial self-efficacy (Brändle et al.,2018). Previous work on missionary identity links the pursuit of social and financial aims to conflicting logics and internal tensions for missionary entrepreneurs (Wry \& York, 2017). We then expect missionaries to give forethought to their ability to accomplish the tasks involved in their entrepreneurship venture to avoid failing in their primary mission and to elude the negative feelings associated. Accordingly, we expect the link from entrepreneurial self-efficacy to entrepreneurial intention to strengthen when identification with a missionary social identity is salient.

Hypothesis 3c: When identification with Missionary social identity is high, the positive relationship between entrepreneurial self-efficacy and entrepreneurial intention is stronger.

\section{Methodology.}

\subsection{Data and Sample.}

The proposed research will rely on data collected through the Global University Entrepreneurial Spirit Students Survey (GUESSS) in its 2016 version. GUESSS is an international research project investigating the entrepreneurial intentions and activities of a global population of university students. The student samples represent a homogeneous population in terms of age and qualification (Liñan \& Chen, 2009) and are widely used in entrepreneurship research. Additionally, student samples are commonly used in such research because academics defend the idea of studying individuals at the earliest possible stage of entrepreneurial activities, which is applied to university students who have not yet decided on their first job. This allows a true prospective view without retrospective bias (Carter et al. 2003) and allows a clearer idea of the formation of entrepreneurial intentions.

The sample consists of 696 students in Colombian higher-education institutions. Colombia is a developing middle-income economy with a favorable environment for entrepreneurship. Colombian legislation specifically requires educational institutions, including universities, to promote an "entrepreneurial spirit" and, the Global Entrepreneurship Monitor (GEM) generally reports very high levels of socio-cultural acceptance of entrepreneurship. Additionally, levels of early-stage entrepreneurial activity in Latin American, including in Colombia, are high, as indicated in GEM surveys. According to the latest GEM report, the country's 2019 total entrepreneurial activity rate is $22.3 \%$ (ranking sixth in latinoamerica), and it is expected to grow over the next four years due to government support policies and programs.

\subsection{Measuremens of variables.}

All variables have been assessed with scales chosen by the GUESSS proyect around the world and using 7-point Likert scales (1=strongly disagree, $7=$ strongly agree). The dependent variable of our model, Entrepreneurial Intention (EI) is measured by the 6-item scale proposed by Liñan \& Chen (2009). The independent variable, Entrepreneurial Self-Efficacy (ESE) is measured following previous studies (Liñan, 2008;). For the founders' social identities, we use the scale developed by Sieger et al. (2016). 
Confirmatory factor analysis (CFA) was realized to evaluate the reliability, unidimensionality, and validity of the scales. The theoretical model shows a reasonable setting according to the fit indicators (see Table I). All indicators have significant loadings on the assigned factor, indicating convergent validity (Bagozzi \& Yi, 1988). The reliability of the constructs is confirmed, as the structural composite reliability values for the five constructs range from 0.83 to 0.89 (Bagozzi \& Yi, 1988). All constructs comply with the 0.5 level with respect to average variance extracted (AVE) (Fornell \& Larcker, 1981). The most stringent test to assess discriminant validity is confirmed according to Fornell \& Larcker (1981), as for every pair of constructs, its squared correlation is never higher than every involved construct's AVE. Moreover, none of the correlation estimates of every pair of constructs include the value 1 in its 99 percent confidence interval ( \pm 3 standard errors of the phi coefficients) (Anderson \& Gerbing, 1988).

Table I. Constructs measurements summary: confirmatory factor analysis and scale reliability.

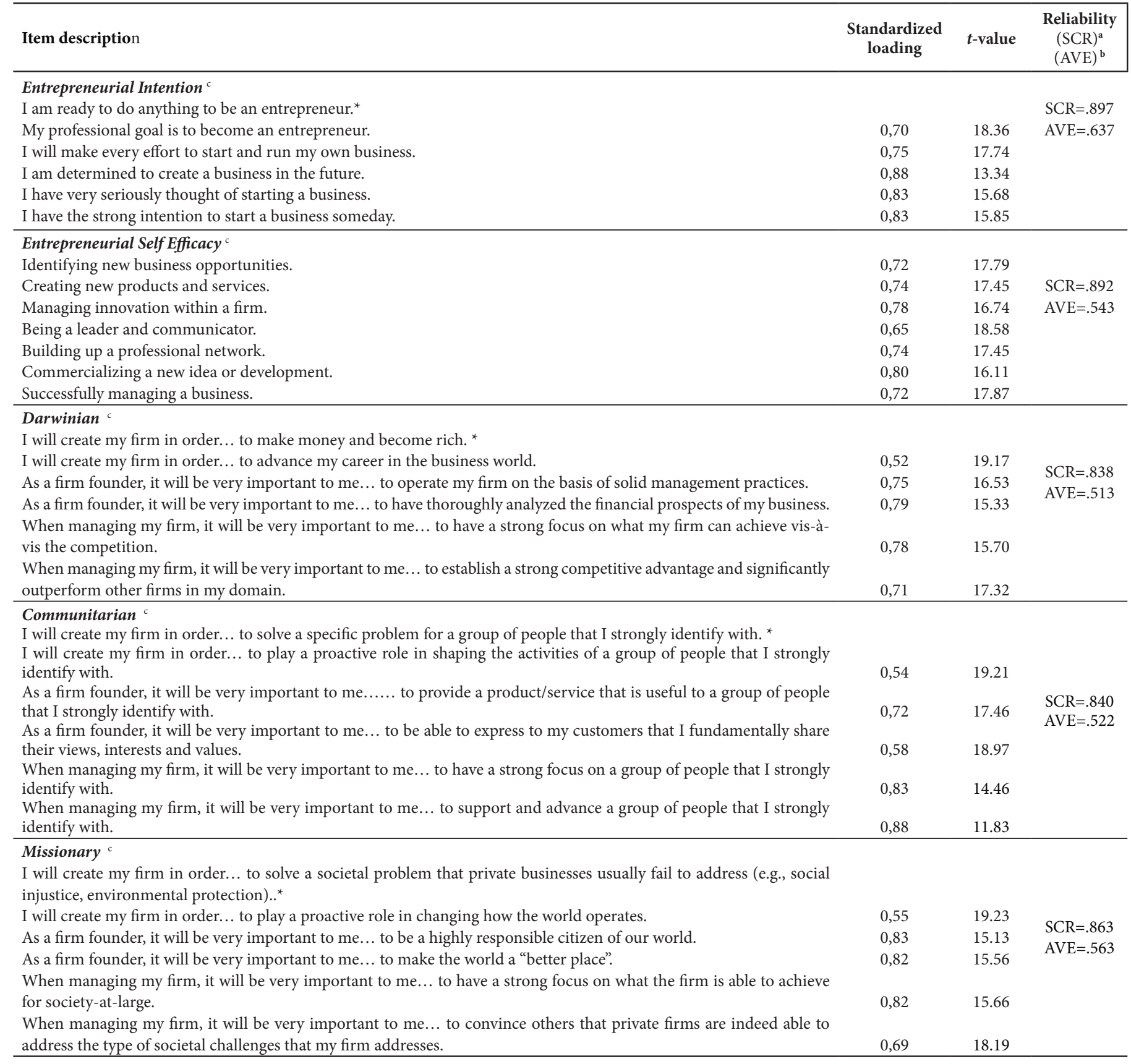

Note(s): This Table shows the standardized loading and T-value for each items of the variables. For each variable the table shows the scale composite reliability index and average variance extracted index. Fit statistics for measurement model of 31 indicators for 5 constructs: $\chi^{2}{ }_{(314)}=1873.57$; GFI= 0.85; RMSEA=0.078; SRMR= 0.058; CFI=0.96; TLI (NNFI) $=0.95$. ${ }^{a}$ Scale composite reliability: $\left(\rho_{\mathrm{c}}=\left(\Sigma \lambda_{\mathrm{i}}\right)^{2} \operatorname{var}(\xi) /\left[\left(\Sigma \lambda_{\mathrm{i}}\right)^{2} \operatorname{var}(\xi)+\sum \theta_{\mathrm{iij}}\right]\right.$; (Bagozzi y Yi, 1998)). baverage variance extracted ${ }^{c}$ scale anchor: $1=$ strongly disagree; $7=$ strongly agree. $\left.{ }^{*}\right)$ Item deleted during the scale-validation process. 


\section{Results.}

The empirical analysis of the theoretical framework which includes direct and moderating effects is performed using a hierarchical OLS regression as proposed by Baron \& Kenny (1986) and as has been used in related studies (Brändle et al., 2018). Starting from a baseline model, we successively enrich the model with different bundles of influencing factors that might explain the dependent variable, entrepreneurial intention. We included, as control variables in our regression model, the gender ( $0=$ female, $1=$ male), its age, education $(1=$ undergraduate,
$2=$ graduate), the family business background ( $0=$ family members were not self-employed, $1=$ if they were) and the entrepreneurial prior experience $(0=$ if yes $1=i f$ no). These are variables commonly used in the entrepreneurial intention literature (e.g. Obschonka et al., 2012).

Table II presents the descriptive statistics and the correlations between all the variables. To eliminate multicollinearity that could result from including the theoretical variables and their interactions in the same equation, we applied the mean-centering method recommended by Jaccard et al. (1990).

Table II. Matrix of correlation and descriptive statistics.

\begin{tabular}{|c|c|c|c|c|c|c|c|c|c|c|c|c|}
\hline Variable & Mean & Standard deviation & 1 & 2 & 3 & 4 & 5 & 6 & 7 & 8 & 9 & 10 \\
\hline 1. Gender & 0,52 & 0,5 & 1,00 & & & & & & & & & \\
\hline 2. Age & 23,29 & 4,58 & 0,03 & 1,00 & & & & & & & & \\
\hline 3. Education Level & 1,06 & 0,23 & 0,00 & $0,38^{\star *}$ & 1,00 & & & & & & & \\
\hline 5. Family Business Background & 0,15 & 0,49 & $-0,04$ & $-0,03$ & $-0,01$ & $-0,02$ & 1,00 & & & & & \\
\hline 6. Entrepreneurial Intention & 6,52 & 0,72 & 0,00 & 0,03 & $-0,37$ & 0,04 & 0,05 & 1,00 & & & & \\
\hline 9. Communitarian Identity & 5,88 & 0,94 & $-0,01$ & $-0,04$ & $-0,03$ & 0,04 & 0,00 & $0,29^{\star *}$ & $0,36^{* *}$ & $0,50^{\star *}$ & 1,00 & \\
\hline 10. Missionary Identity & 6,16 & 0,89 & 0,00 & 0,03 & 0,02 & 0,00 & 0,04 & $0,37^{* *}$ & $0,44^{\star *}$ & $0,56^{\star *}$ & $0,60^{\star *}$ & 1,00 \\
\hline
\end{tabular}

Note(s): This table shows the means, standard deviation and correlations between variables $\mathrm{N}=696{ }^{*} p<0.05$ (2 tailed); ${ }^{* *} p<0.01$ (2-tailed)

Hypotheses were tested using a three-step hierarchical regression analysis, adding variables in each step. An initial regression was performed with the control variables. In a second step, the direct effects of entrepreneurial self-efficacy (ESE), Darwinian Identity (DAR),
Communitarian Identity (COM) and Missional identity (MIS) on entrepreneurial intention (EI) were added. Finally, interaction terms were included. The results presented in Table III confirm, first, that the control variables have no impact on EI (Model 1).

Table III. Regression analysis results

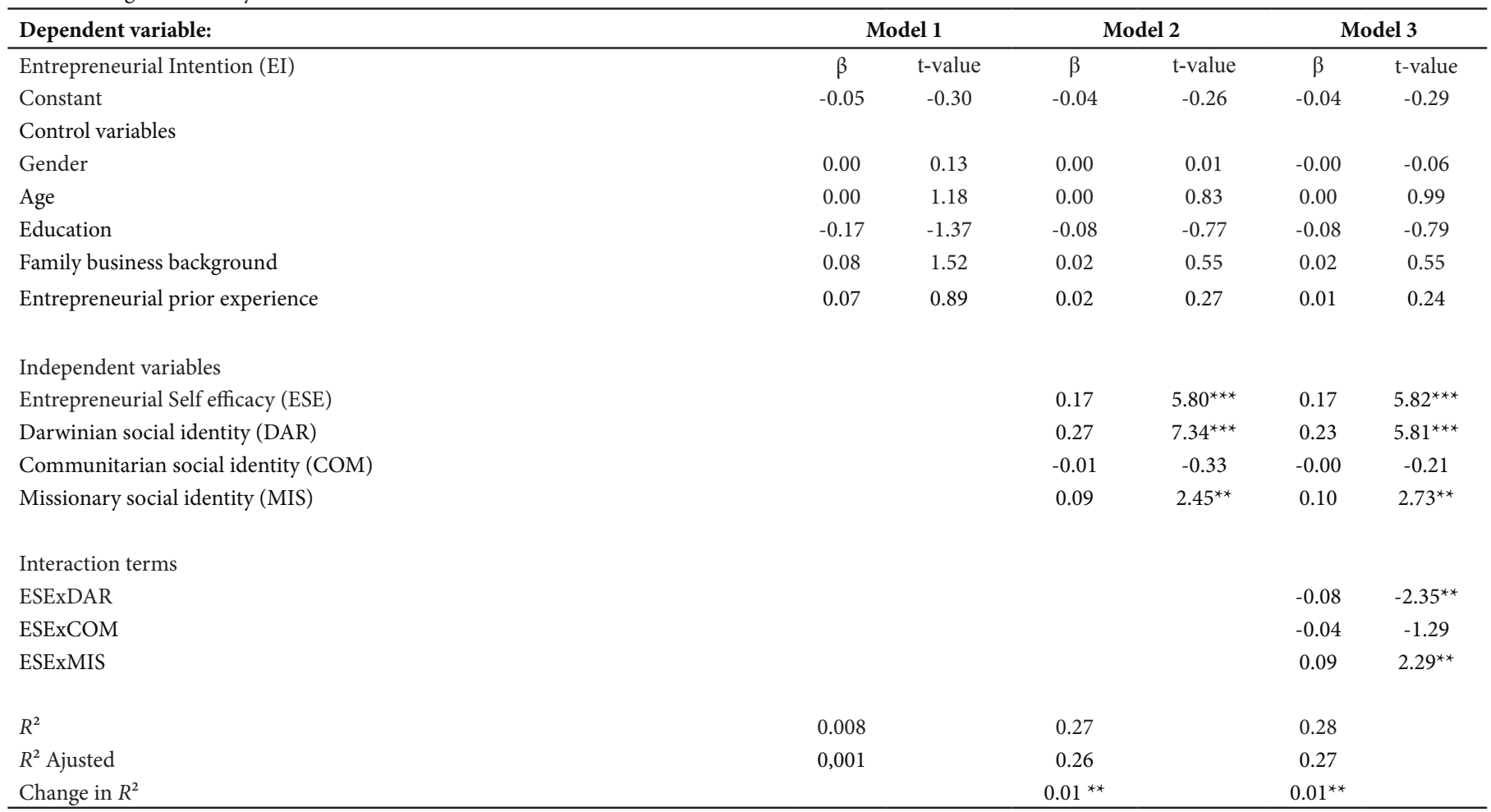

Note(s): This table shows the coefficient estimates for each model and sgnificances. Significance levels on a two-tailed test ${ }^{* *} p<.01 ;{ }^{* *} p<.05 ;{ }^{*} \mathrm{p}<.1$ 
The addition of the direct effect terms (Model 2) yielded a significant increase in $R^{2}\left(\Delta R^{2}=0.26 p<0.05\right)$. Finally, the complete model, including the interactions terms (Model 3), presented a significant increase in explanatory power $\left(\Delta \mathrm{R}^{2}=0.01 \mathrm{p}<0.05\right)$. Therefore, Model 3 was selected for our analysis. This model shows a significant and positive impacts of the direct effect terms, excepted by communitarian social identity term $(\beta=0.17 \mathrm{p}<0.01$ for ESE, $\beta=0.23 \mathrm{p}<0.01$ for DAR and, $\beta=0.10 \mathrm{p}<0.05$ for MIS). H2a, H2b and $\mathrm{H} 2 \mathrm{c}$ predicted positive relationships between founders' social identities and entrepreneurial intention. Darwinian and missionary identity received strong empirical support, while communitarian identity did not. The positive relationship between ESE and EI was supported by the results confirming findings in previous studies (H1).

Additionally, moderation analysis showed that the positive relation between ESE and EI is negatively moderated by entrepreneurs' Darwinian social identity $(\beta=-0.08 p<0.05)$ confirming H3a. Empirical results also found support for the positive moderating effect of missionary identity on the positive relationship between ESE and entrepreneurial intention, laid out on $\mathrm{H} 3 \mathrm{c}(\beta=0.09 \mathrm{p}<0.05)$. Finally, $\mathrm{H} 3 \mathrm{~b}$ stipulated a negative moderation effect of Communitarian social identity on the positive relationship between ESE and EI did not find empirical support.

\section{Discussion and conclusions}

Our results show that for Darwinian and Missionary entrepreneurs both self-perception of entrepreneurship-related capacities and perceived identity influence positively and directly the entrepreneurial intention. Darwinians and Missionaries are similar in terms of targeting for an a priori defined goal, even if greatly different. Darwinian entrepreneurs enact their identity as money-oriented entrepreneurs by developing their businesses while missionaries enact theirs as world-changers by creating businesses that align with their societal goals. This is not the first study in which these different identities are found to share similarities. Darwinians and missionaries have been found to engage predominantly on causal behavior while communitarians make greater use of effectual reasoning (Alsos et al., 2016).

These findings contribute to filing the gap in the literature which mentioned that the relationship between entrepreneurs' social identity and entrepreneurial intention had not been sufficiently studied and heterogeneity in social identities had often been despised. Adopting a multiple identity lens allows us to understand the effects that differences in basic social motivation, basis of self-evaluation and frame of reference of entrepreneurs have. Furthermore, this research responds to call recently made by Levfebre et al. (2021) to explore entrepreneurial identity in emerging economies to broad the understanding in different cultural contexts.

Having a Communitarian social identity does not seem to influence entrepreneurial intention meaning that being a Communitarian does not have a significant influence on the development of entrepreneurial intention. This could be explained by the fact that communitarians usually engage in entrepreneurship almost accidentally while developing a product/service for themselves which under adequate conditions is recognized as valuable by their group members who give positive feedback encouraging communitarians to develop business (Oo et al., 2019). Culture might also be another reason for the non-significance of the relationship between Communitarian identity and entrepreneurial intention. Cultural factors as uncertainty avoidance and individualism/collectivism have proven to influence communitarian founders (Estrada Cruz et al., 2019).

We also found that entrepreneurial self-efficacy and an entrepreneur's social identity interact for the development of entrepreneurial intention in a dissimilar way. Darwinian entrepreneurs consider themselves natural firm founders and thus, creating a business is for them a natural path. They do not question themselves, neither their abilities. On the other hand, missionaries use entrepreneurship as a way to fulfill their societal goals and auto-impose a great responsibility to "change the world" which can lead to anxiety for not having enough entrepreneurship-related abilities. Furthermore, according to entrepreneurial self-efficacy (ESE) literature and recent research agenda proposed by Newman et al. (2019) and related with limited attention placed on situations where ESE is less or more potent, our findings allow us to understand why some individuals with low entrepreneurial self-efficacy exhibit strong entrepreneurial intention. Individuals who exhibit a low entrepreneurial self-efficacy but whose Darwinian identity is salient will still engage in entrepreneurial intention despite their entrepreneurial self-efficacy as they rely more on their perceived identity and less on their perceived abilities when deciding to engage in entrepreneurship. For communitarians, the interaction effect of entrepreneurial self-efficacy and identity was not significant. This result is unexpected as group membership had previously been found to interact with entrepreneurial self-efficacy in the formation of intentions (Terry \& Hogg, 1996).

Only a handful of entrepreneurship studies had considered both perceived ability and perceived identity simultaneously. Our results confirm the importance of analyzing both perceived abilities and perceived identity together and to consider social identity as a multidimensional concept. Entrepreneurs are not all just entrepreneurs. They are either money-oriented, community-oriented or society -oriented and thus they strongly identify with themselves, their proximal others or society as a whole, and this identification has a differentiated effect on their entrepreneurial intention and on the relationship between their perceived abilities and their intention to become entrepreneurs.

Despite the growing interest in self-perception in the current entrepreneurship literature, this is one of the first studies to analyze together both self-efficacy and self-identity. In particular, this study proposes an explanation of including action in entrepreneurial cognition research infusing into social-situation-based theorizing, the notion that the mind is much more than a sum of parts and the interdependence between individual beliefs and his or her immediate social context may be the key to further explaining what leads to the formation of entrepreneurial behaviors (Randolf-Seng et al., 2015). Moreover, we move away from the consideration of entrepreneurial identity as a 
unitary concept and we use the multiple social identities proposed by Fauchart \& Gruber (2011). Using a social and self-identity focus, this research shows that having a Darwinian or Missionary social identity influences the generation of entrepreneurial intentions, additionally, it shows that these identities interact with entrepreneurial self-efficacy in opposing ways. This opens up the opportunity to extend this study by evaluating how Fauchart and Gruber's social identities interact with other Theory of Planned Behavior's determinants.

These results yield implications with potential for use in both theory and practice. In general terms, our findings confirm that identity theory serves as a fruitful perspective from which to expand understanding of entrepreneurship. This approach includes the different meanings that founders associate with the creation of a new firm and confirms these connotations impact entrepreneurial intention. Entrepreneurial training programs focus mostly on assisting entrepreneurs to develop their business ideas and related business plans. However, because the entrepreneurial identity is such a key element in the entrepreneurship process, the programs would benefit from placing focus also on assisting the potential entrepreneurs in entrepreneurial identity work (Smith \& Woodworth, 2012). Moreover, in the growing field of entrepreneurial identity research, contributions are being made to the importance of innovation. Innovation is essential to the entrepreneurship process to the implementation of creative ideas for business ventures. Identity formation is a constant social process of searching for information that shapes entrepreneurial behavior. It also makes it possible to help individuals harvest innovations related to their passions and emotions (Zhou et al., 2020). Thus, there is a potential vein to fill the gap that scholars recently have called to research the relationship between innovation, and entrepreneurship.

Our study has some limitations that suggest further research. First, our results may be context-specific, and further research may contribute by considering such issues. Second, the data based on the perceptions of individual respondents is inevitably subjective in nature. Additionally, the cross-sectional nature of our study brings some limitations. The development of one's social identity is typically a long-term process. Longitudinal research projects would be useful in clarifying the causal relationships between the concepts in this study.

\section{References}

Alsos, G. A., Clausen, T. H., Hytti, U., \& Solvoll, S. (2016). "Entrepreneurs' social identity and the preference of causal and effectual behaviors in start-up processes", Entrepreneurship \& Regional Development, 28(3-4), 234-258. https://doi.org/10.1080/08985626.2016.1 155742

Anderson, J. C., \& Gerbing, D. W. (1988). Structural equation modeling in practice: A review and recommended two-step approach, Psychological Bulletin, 103 (3), 411-423.

Bagozzi, R. P., \& Yi, Y. (1988). On the evaluation of structural equation models. Journal of the academy of marketing science, 16(1), 74-94. https://doi.org/10.1007/BF02723327
Bandura, A. (1982). Self-efficacy mechanism in human agency, American Psychologist, 37 (2), 122-147. https://doi.org/10.1037/0003066X.37.2.122

Baron, R. M., \& Kenny, D. A. (1986). The moderator- Mediator variable distinction in social psychological research: Conceptual, strategic, and statistical considerations, Journal of Personality and Social Psychology, 51(6), 1173-1182.

Brändle, L., Berger, E. S., Golla, S., \& Kuckertz, A. (2018). I am what I am-How nascent entrepreneurs' social identity affects their entrepreneurial self-efficacy. Journal of Business Venturing Insights, 9, 17-23, https://doi.org/10.1016/j.jbvi.2017.12.001

Carter, N. M., Gartner, W. B., Shaver, K. G., \& Gatewood, E. J. (2003). The career reasons of nascent entrepreneurs. Journal of Business Venturing, 18(1), 13-39. https://doi.org/10.1016/S0883-9026(02)00078-2

Ceresia, F., \& Mendola, C. (2020). Am I an entrepreneur? Entrepreneurial self-identity as an antecedent of entrepreneurial intention. Administrative Sciences, 10(3), 46. https://doi.org/10.3390/admsci10030046

Charng, H.W., Piliavin, J.A. \& Callero, P.L. (1988). Role identity and reasoned action in the predication of repeated behavior. Social Psychology Quarterly, 51, 303-317.

Donaldson, C. (2019). Intentions resurrected: a systematic review of entrepreneurial intention research from 2014 to 2018 and future research agenda. International Entrepreneurship and Management Journal, 15, 953-975. https://doi.org/10.1007/s11365-019-00578-5

Daskalopoulou, A., \& Skandalis, A. (2019). Consumption field driven entrepreneurship (CFDE). European Journal of Marketing, 53(1), 63-82. https://doi.org/10.1108/EJM-06-2017-0424

Estrada Cruz, M., Verdú Jover, A. J., \& Gómez Gras, J. M. (2019). The influence of culture on the relationship between the entrepreneur's social identity and decision-making: Effectual and causal logic, $\mathrm{Bu}$ siness Research Quarterly, 22 (4), 226-244. https://doi.org/10.1016/j. brq.2018.10.002

Fauchart, E., \& Gruber, M. (2011). Darwinians, communitarians, and missionaries: The role of founder identity in entrepreneurship, Academy of Management Journal, 54(5), 935-957. https://doi. org/10.5465/amj.2009.021

Fitzsimmons, J. R., \& Douglas, E. J. (2011). Interaction between feasibility and desirability in the formation of entrepreneurial intentions, Journal of Business Venturing, 26(4), 431-440. https://doi. org/10.1016/j.jbusvent.2010.01.001

Fornell, C., \& Larcker, D. F. (1981). Evaluating structural equation models with unobservable variables and measurement error, Journal of Marketing Research, 18(1), 39-50. https://doi. org/10.1177/002224378101800104 
Gruber, M., \& MacMillan, I. C. (2017). Entrepreneurial behavior: A reconceptualization and extension based on identity theory, Strategic Entrepreneurship Journal, 11(3), 271-286. https://doi.org/10.1002/sej.1262

Hand, C., Iskandarova, M., \& Blackburn, R. (2020). Founders' social identity and entrepreneurial self-efficacy amongst nascent entrepreneurs: A configurational perspective. Journal of Business Venturing Insights, 13(C). https://doi.org/10.1016/j.jbvi.2020.e00160

Hogg, M. A., \& Hains, S. C. (1998). Friendship and group identification: A new look at the role of cohesiveness in groupthink, European Journal of Social Psychology, 28(3), 323-341. https://doi.org/10.1002/ (SICI)1099-0992(199805/06)28:3<323::AID-EJSP854>3.0.CO;2-Y

Jaccard, J., Wan, C. K., \& Turrisi, R. (1990). The detection and interpretation of interaction effects between continuous variables in multiple regression. Multivariate behavioral research, 25(4), 467-478. https://doi.org/10.1207/s15327906mbr2504_4

Ko, E.J. \& Kim, K. (2020), Connecting founder social identity with social entrepreneurial intentions, Social Enterprise Journal, 16(4), 403-429. https://doi.org/10.1108/SEJ-02-2020-0012

Lheureux, F., \& Auzoult, L. (2017). Me, an entrepreneur ? Entrepreneurial identity, outgroup social identification, attitudes and intentions towards business creation, Revista de Psicología Social, 32(2), 246-275. https://doi.org/10.1080/02134748.2017.1291744

Liñan, F., \& Chen, Y. W. (2009). Development and cross-cultural application of a specific instrument to measure entrepreneurial intentions, Entrepreneurship Theory and Practice, 33(3), 593-617. https:// doi.org/10.1111/j.1540-6520.2009.00318.x

Murnieks, C. Y., Cardon, M. S., \& Haynie, J. M. (2020). Fueling the fire: Examining identity centrality, affective interpersonal commitment and gender as drivers of entrepreneurial passion, Journal of Business Venturing, 35(1), https://doi.org/10.1016/j.jbusvent.2018.10.007

Newman, A., Obschonka, M., Schwarz, S., Cohen, M., \& Nielsen, I. (2019). Entrepreneurial self-efficacy: A systematic review of the literature on its theoretical foundations, measurement, antecedents, and outcomes, and an agenda for future research, Journal of Vocational Behavior, 110(b), 403-419. https://doi.org/10.1016/j.jvb.2018.05.012

Obschonka, M., Goethner, M., Silbereisen, R. K., \& Cantner, U. (2012). Social identity and the transition to entrepreneurship: The role of group identification with workplace peers, Journal of Vocational Behavior, 80(1), 137-147. https://doi.org/10.1016/j.jvb.2011.05.007

Obschonka, M., Silbereisen, R. K., Cantner, U., \& Goethner, M. (2015). Entrepreneurial self-identity: predictors and effects within the theory of planned behavior framework. Journal of Business and Psychology, 30(4), 773-794. https://doi.org/10.1007/s10869-014-9385-2
Oo, P. P., Allison, T. H., Sahaym, A., \& Juasrikul, S. (2019). “User entrepreneurs' multiple identities and crowdfunding performance: Effects through product innovativeness, perceived passion, and need similarity", Journal of Business Venturing, 34(5). https://doi.org/10.1016/j. jbusvent.2018.08.005.

Radu-Lefebvre, M., Lefebvre, V., Crosina, E., \& Hytti, U. (2021). Entrepreneurial Identity: A Review and Research Agenda. Entrepreneurship Theory and Practice, https://doi.org/10.1177/10422587211013795.

Randolph-Seng, R. K. Mitchell, H. Vahidnia, J. R. Mitchell, S. Chen, and J. Statzer. (2015). The Microfoundations of Entrepreneurial Cognition Research: Toward an Integrative Approach. Foundations and Trends in Entrepreneurship, 11(4), 207-335. https://DOI: $10.1561 / 0300000055$.

Shepherd, D. A., Williams, T. A., \& Patzelt, H. (2015). Thinking about entrepreneurial decision making: Review and research agenda, Journal of Management, 41(1), 11-46. https://doi. org/10.1177/0149206314541153

Sieger, P., Gruber, M., Fauchart, E., \& Zellweger, T. (2016). Measuring the social identity of entrepreneurs: Scale development and international validation, Journal of Business Venturing, 31(5), 542-572. https://doi.org/10.1016/j.jbusvent.2016.07.001

Smith, I. H., \& Woodworth, W. P. (2012). Developing Social Entrepreneurs and Social Innovators: A Social Identity and Self-Efficacy Approach. Academy of Management Learning \& Education, 11(3), 390-407. https://doi.org/10.5465/amle.2011.0016

Super, D. E. (1963). Self-concepts in vocational development, Career development: Self-concept theory (pp. 1-16). New York, NY: College Entrance Examination Board.

Terry, D. J., \& Hogg, M. A. (1996). Group norms and the attitudebehavior relationship: A role for group identification, Personality and Social Psychology Bulletin, 22(8), 776-793. https://doi. org/10.1177/0146167296228002

Wry, T., \& York, J. G. (2017). An Identity-Based Approach to Social Enterprise, Academy of Management Review, 42(3), 437-460. https:// doi.org/10.5465/amr.2013.0506

Zhou, J., Xu, X., Li, Y., \& Liu, C. (2020). Creative enough to become an entrepreneur: A multi-wave study of creative personality, education, entrepreneurial identity, and innovation. Sustainability, 12(10), 4043. https://doi.org/10.3390/su12104043 
